\title{
PEMANFAATAN GAS HYDROCARBON UNTUK SISTEM BAHAN BAKAR SEPEDA MOTOR
}

\author{
Gugun Gundara \\ Program Studi Teknik Mesin, Fakultas Teknik, Universitas Muhammadiyah Tasikmalaya \\ Jl. Tamansari km 2.5 Gobras, Tasikmalaya Kode pos 46196 \\ Telp. 02652350982 \\ E-mail: gugun@umtas.ac.id
}

\begin{abstract}
Abstrak
Bahan bakar merupakan bagian yang tidak dapat dipisahkan dari siklus kerja suatu mesin kendaraan, banyak sekali jenis bahan bakar yang bisa digunakan untuk menunjang pada performance mesin kendaraan yang telah muncul dipasaran antara lain bensin dan pertamax. Disini penulis berhasil mengembangkan suplement bahan bakar guna menyempurnakan pembakaran selain bahan bakar yang telah disebutkan diatas. Gas merupakan zat yang diakibatkan dari penguapan yang bisa teradapat pada zat cair termasuk juga pada bahan bakar. Disini penulis mencoba memanfaatkan gas yang berada pada bahan bakar yang digunakan pada kendaraan baik itu bensin maupun pertamax, gas tersebut digunakan sebagai suplement supaya bahan bakar tersebut bisa dimanfaatkan sepenuhnya tetapi dengan cara diolah terlebih dahulu dengan cara yang khusus. Dari analisis ini dihasilkan rekomendasi terbaik untuk penggunaan suplement bahan bakar pada kendaran yang bisa membuat kendaraan tersebut lebih irit dan bertenaga di akibatkan pembakaran yang sempurna.
\end{abstract}

Kata Kunci: bahan bakar, bensin, hydrocarbon, pertamax

\section{PENDAHULUAN}

Senyawa karbon yang paling sederhana adalah hydrocarbon karena hanya terdiri dari dua unsur, yaitu karbon $(\mathrm{C})$ dan hidrogen $(\mathrm{H})$, Seluruh hydrocarbon memiliki rantai karbon dan atom-atom hidrogen yang berikatan dengan rantai tersebut. Bahan bakar merupakan salah satu media yang terdapat pada sistem bahan bakar yang berkaitan dengan performance kendaraan. Ada beberapa jenis bahan bakar diantaranya pertalite, premium dan pertamax, setiap kendaraan bahan bakarnya telah diatur sedemikian rupa dengan perbandingan tertentu, perbandingan tersebut bisa berdampak pada banyak sedikitnya bahan bakar yang dikonsumsi dan berujung pada ketersediaan budget.

Setiap kendaraan ingin mempunyai sistem bahan bakar yang sempurna, irit dan bertenaga, oleh sebab itu perlu pemanfatan jenis bahan bakar lain, selain bahan bakar yang digunakan seperti hydrocarbon yang berasal dari uap bahan bahan bakar. Tujuan penelitian ini adalah ingin menemukan manfaat gas hydrocarbon sebagai suplemen pada bahan bakar kendaraan.

\section{METODOLOGI}

Cara pengoperasian alat ini dengan mengisikan 500cc pertamax kedalam tangki reservoir (seperti halnya cara hydrogen air yang sedang populer saat ini) kemudian uap bahan bakar minyak ini (pertamax) disalurkan ke intake Carburator dengan melalui sebuah pipa katalis yg bisa memecah pertamax menjadi hydrogen rich dan menghisap unsur partikel carbon sehingga nantinya pada knalpot / gas buang unsur carbon monoxida bisa berkurang secara signifikan dan hydrogen sebagai penambah oktan pada kendaraan tersebut. 


\section{HASIL DAN PEMBAHASAN}

\section{Pengukuran Pemakaian Bahan Bakar Pertamax}

Gas Hydrocarbon yang dihasilkan dari bahan bakar pertamax mampu menaikan efesiensi konsumsi bahan bakar selama 1 jam. Konsumsi bahan bakar berbanding lurus dengan putaran mesin, semakin tinggi putarannya maka pemakaian bahan bakar semakin besar pula. Dengan menggunakan hydrocarbon crack system memberikan perbedaan yaitu konsumsi bahan bakar menjadi semakin irit.

Tabel 1. Rata - Rata Pengukuran Pemakaian Bahan Bakar Pertamax Dengan HCS dalam Satuan Millimeter (mm)

\begin{tabular}{|c|c|c|}
\hline Putaran & Gigi 1 & Gigi 2 \\
\hline 1600 rpm & $0,05 \mathrm{~mm}$ & $0,03 \mathrm{~mm}$ \\
\hline $\mathbf{1 8 0 0} \mathbf{~ r p m}$ & $0,07 \mathrm{~mm}$ & $0,07 \mathrm{~mm}$ \\
\hline $\mathbf{2 0 0 0} \mathbf{~ r p m}$ & $0,69 \mathrm{~mm}$ & $0,07 \mathrm{~mm}$ \\
\hline $\mathbf{2 2 0 0} \mathbf{~ r p m}$ & $1,03 \mathrm{~mm}$ & $0,39 \mathrm{~mm}$ \\
\hline
\end{tabular}

\begin{tabular}{|c|c|c|}
\hline Putaran & Gigi 3 & Gigi 4 \\
\hline 1600 rpm & $0,02 \mathrm{~mm}$ & $0,01 \mathrm{~mm}$ \\
\hline 1800 rpm & $0,03 \mathrm{~mm}$ & $0,02 \mathrm{~mm}$ \\
\hline 2000 rpm & $0,05 \mathrm{~mm}$ & $0,03 \mathrm{~mm}$ \\
\hline $\mathbf{2 2 0 0}$ rpm & $0,08 \mathrm{~mm}$ & $0,06 \mathrm{~mm}$ \\
\hline
\end{tabular}

Tabel 2. Rata - Rata Pengukuran Pemakaian Bahan Bakar Pertamax Tidak Pakai HCS dalam Satuan Millimeter (mm)

\begin{tabular}{|c|c|c|}
\hline Putaran & Gigi 1 & Gigi 2 \\
\hline $\mathbf{1 6 0 0} \mathbf{~ r p m}$ & $2,10 \mathrm{~mm}$ & $1,60 \mathrm{~mm}$ \\
\hline $\mathbf{1 8 0 0} \mathbf{~ r p m}$ & $3,07 \mathrm{~mm}$ & $2,43 \mathrm{~mm}$ \\
\hline $\mathbf{2 0 0 0} \mathbf{~ r p m}$ & $5,00 \mathrm{~mm}$ & $4,50 \mathrm{~mm}$ \\
\hline $\mathbf{2 2 0 0} \mathbf{~ r p m}$ & $5,73 \mathrm{~mm}$ & $5,10 \mathrm{~mm}$ \\
\hline
\end{tabular}

\begin{tabular}{|c|c|c|}
\hline Putaran & Gigi 3 & Gigi 4 \\
\hline 1600 rpm & $1,07 \mathrm{~mm}$ & $0,07 \mathrm{~mm}$ \\
\hline $\mathbf{1 8 0 0} \mathbf{~ r p m}$ & $2,17 \mathrm{~mm}$ & $1,47 \mathrm{~mm}$ \\
\hline $\mathbf{2 0 0 0} \mathbf{~ r p m}$ & $4,07 \mathrm{~mm}$ & $3,37 \mathrm{~mm}$ \\
\hline $\mathbf{2 2 0 0} \mathbf{~ r p m}$ & $4,97 \mathrm{~mm}$ & $3,93 \mathrm{~mm}$ \\
\hline
\end{tabular}

\section{Pengolahan Data Pemakaian Bahan Bakar Pertamax}

Perhitungan Pemakaian Bahan Bakar Dalam Liter/Jam

Diketahui :

$$
\begin{aligned}
& \mathrm{d}=6,5 \mathrm{~cm}=65 \mathrm{~mm} \\
& \mathrm{r}=32,5 \mathrm{~mm} \\
& \mathrm{t}=0,046667 \\
& \text { Waktu }=60 \text { detik }=1 \text { menit } \\
& \quad=1 \text { jam }=60 \text { menit }
\end{aligned}
$$

Ditanya : V

Grafik Perbandingan Pemakaian Bahan Bakar Pertamax

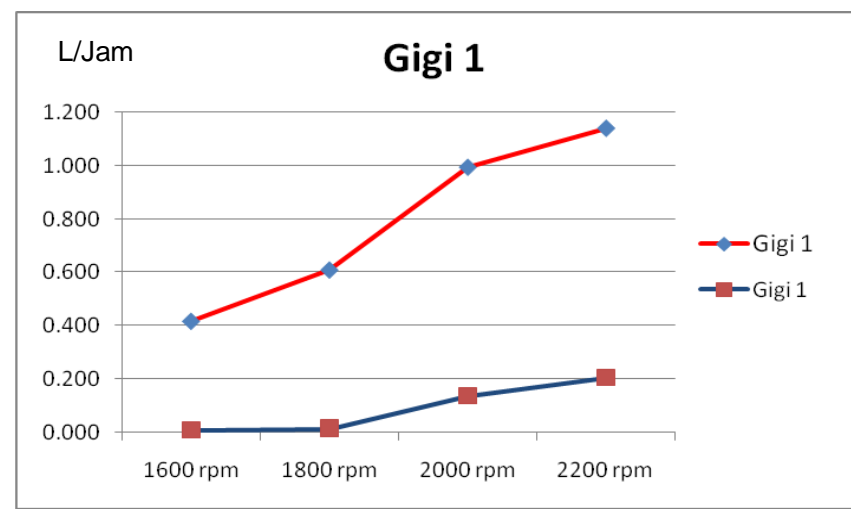

Grafik 1. Penggunaan Bahan Bakar Pertamax Pada Gigi 1 


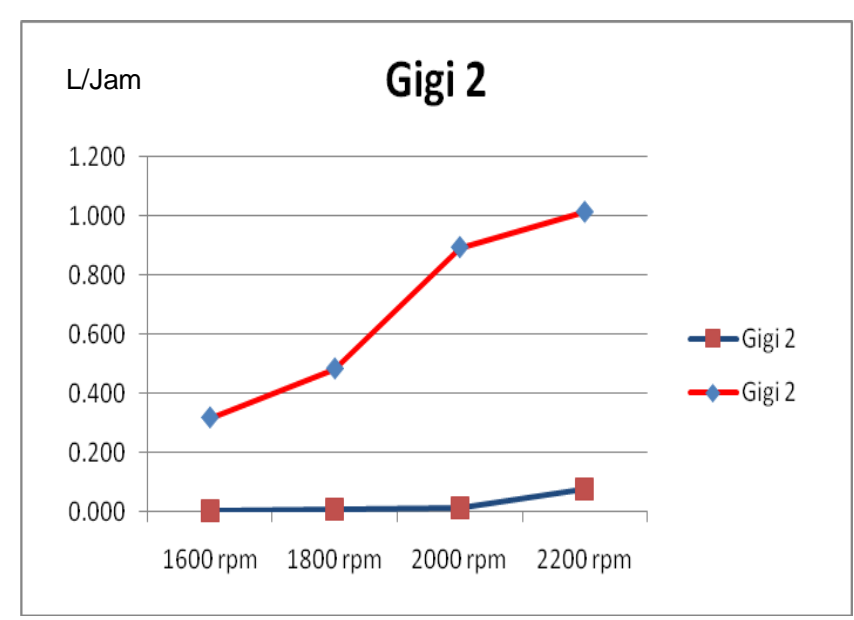

Grafik 2. Penggunaan Bahan Bakar Pertamax Pada Gigi 2

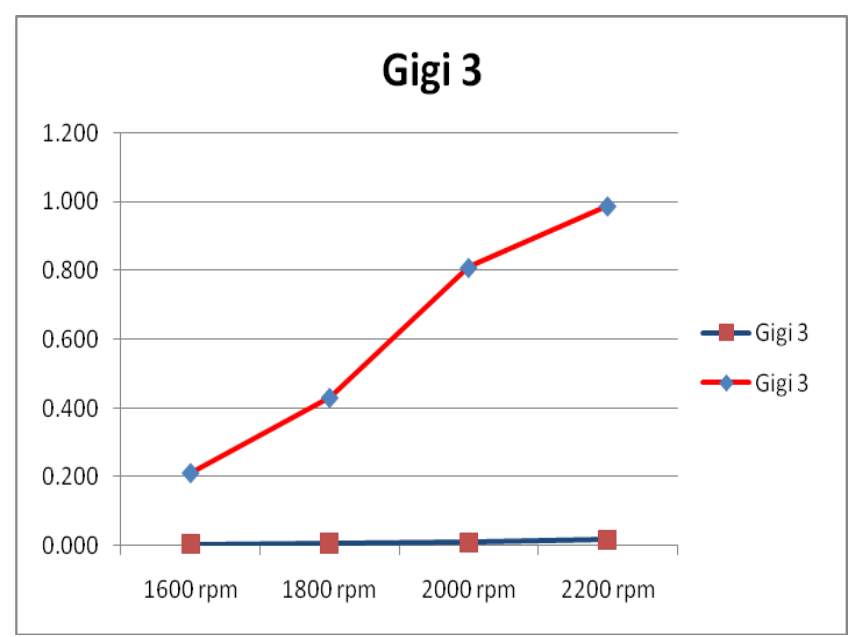

Grafik 3. Penggunaan Bahan Bakar Pertamax Pada Gigi 3

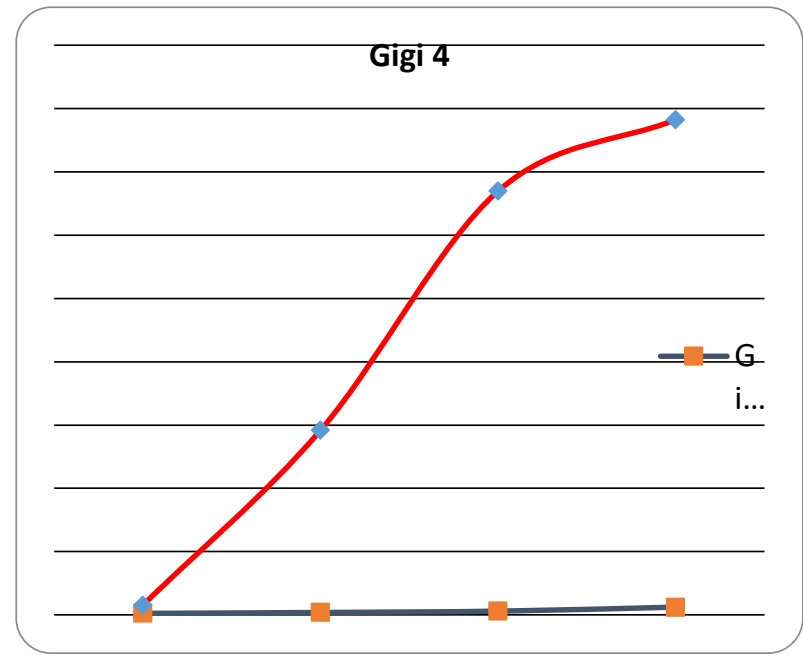

Grafik 4. Penggunaan Bahan Bakar Pertamax Pada Gigi 4

\section{Pembahasan}

Hasil pengamatan, didapatkan bahwa ada perbedaan pemakaian Hydrocarbon Crack System dan tidak pakai Hydrocarbon Crack System. Dimana Hydrocarbon Crack System mampu menekan laju pemakaian bahan bakar dimana uap pertamax yang melalui tangki reservoir disalurkan ke intake Carburator dengan melalui sebuah pipa katalis yg bisa memecah pertamax menjadi hydrogen rich. Hyndrocarbon digunakan sebagai penambah oktan sehingga tidak merusak komponen.

\section{KESIMPULAN}

Manfaat hydrocarbon mampu menurunkan efisiensi konsumsi bahan bakar dengan kapasitas sebanyak 500cc, bahan bakar yang di gunakan adalah jenis bahan bakar pertamax, tidak merusak komponen kendaraan, mudah perawatannya, ramah lingkungan, dan digunakan di berbagai jenis kendaraan roda dua atau pun roda empat.

\section{DAFTAR PUSTAKA}

Dasar Motor Bakar. Desember 2011,http://ww.scribd.com/doc/72782873 IDASAR MOTOR BAKAR, 13 
Haryono, G. 1997. Uraian Praktis Mengenal Motor Bakar. Penerbit Aneka Ilmu Semarang.

Laki, Gunawan, Gede., analisis konsumsi bahan bakar motor bensin yang terpasang pada sepeda motor suzuki smash 110cc yang digunakan pada jalan menanjak, ejournal.unsrat.ac.id, vol. 1 no.1 2012.

Parende, F 2012. Analisis Konsumsi Bahan Bakar Motor Bensin Yang Terpasang Pada Sepeda Motor Suzuki Smash 110cc

Pudjanarsa, A., Nursuhud, D. 2006. Mesin Konversi Energi. Penerbit Andi. Yogyakarta.

Suratman M., S.Pd. Pemeliharaan/Servis Sistem Bahan Bakar Bensin dan Diesel. Armiko. Bandung. 